\title{
THE MEANING OF FOOD IN THE NOVEL PEONY IN LOVE
}

\author{
Dorota Brzozowska \\ Associate Professor \\ University of Opole, Poland \\ e-mail:dbrzozowska@uni.opole.pl
}

\begin{abstract}
The aim of the paper is to show universal and culture-specific meanings of food, taking into consideration different roles nutrition plays in human life. The complicated nature of relations between people and their meals is illustrated with examples from literature, based on the book Peony in Love by Asian American contemporary author Lisa See. The book makes a good example of the subject of food and culture as the main plot is connected with traditional Chinese opera that influenced young women to die of starvation because of love sickness. The Peony Pavilion (Chinese: 牡丹亭; pinyin: Mǔdān tíng) is a play written by Tang Xianzu in the Ming Dynasty and first performed in 1598, but its message is still valid today.
\end{abstract}

Keywords: anorexia, Chinese, food, ghosts, illness, Lisa See, novel

\section{INTRODUCTION}

Food together with air and water are metabolic requirements for human survival and as such they are considered to be the most important physiological needs that should be met first. If these requirements are not met, the human body cannot function properly and will ultimately fail. Apart from the biological function of food, there are several others. One of them is psychological (connected with such needs as love and security), another is worldview (showing such attitudes as vegetarianism or religion, e.g., being kosher), the third one is social (initiation and maintaining interpersonal relations), the next one is cultural (winning the food as spiritus movens of civilization, cuisine, aesthetics of eating), and the last one is economic (product destined to be sold, advertised, consumed) (Niewiadomska \& Kulik \& Hajduk 2005: 43). The role of nourishment differs and changes in cultures, but it seems that in rich countries nowadays a food cult may be observed. The shops are full of exotic products, the media promote and advertise different types of food, master chef programs are popular, cookbooks are printed, and websites with recipes are blossoming 
together with new diets and eating trends; also food studies are prospering well at universities. Increasingly often, people discuss what they have eaten or plan to prepare; they travel in pursuit of new tastes and take photographs of their dishes, and choose their food more consciously, counting calories or looking for taste, health, being nature friendly, etc. Eating is more and more often connected with philosophical attitudes and lifestyle - it fulfils needs on higher levels of Maslow's hierarchy (Maslow 1954).

Attitudes towards food are also linked with the ways people try to conquer hunger and restrain themselves from eating. Aristotle introduced to philosophy the ideal of moderation in moral virtue. The idea was followed by Saint Thomas Aquinas and the Christian thought. Latin medium virtutis is the means of keeping proportion in every virtue with respect to all the different desires that are constitutive of the human appetite (Zwoliński 2006: 426). Every virtue "begins in the reason and ends in the appetite", claimed Aquinas. To make sure humans rule over body desires, they should not cross the borders in their attitudes towards themselves and others (ibid.: 444). Thus, temperance plays an important role in shaping their characters. It consists in not eating and drinking more than necessary, and not being either too greedy or too dainty in regard to the nourishment one takes. Fasting periods are known in many religions and are popular in various types of diets due to their purifying effect. In the Eastern thought, restraint is also valued. The ideal virtue of moderation was preached by Confucius, inter alia, who claimed that no one was harmed by modesty of eating. Meat and strong spices should be eaten with care, and wine should be drunk according to savoir vivre (cf. ibid.: 426).

In many literary works, one can find examples of food treated as a vital nutritious element or as poison, as a source of pleasure or suffering, as a way of showing passions or feelings, as a subject of art in paintings or poems - and as means of control, just to name a few of the very complex ways in which food has functioned in societies - both the traditional and the modern one. Not only abundance of food but also its deprivation makes vital subjects in the history of language and culture. The aim of the paper is to highlight different customs, rituals, and beliefs about food as seen from intercultural perspective and present in the Peony in Love novel.

Although the novel pictures historic times and is a work of fiction, it is connected with the reality on many levels. Lisa See claims that The Three Wives' Commentary had a special influence on her as she researched a great amount of writing done by Chinese women in the seventeenth century, most of it largely unknown today. She came across The Three Wives' Commentary - the first book to have been written by the three wives and to have been published anywhere in the world - Chen Tong (Peony), Tan Ze, and Qian Yi - the wives of Wu Ren 
in the novel. Peony in Love could also be seen as a book about anorexia - an eating disorder illness.

\section{THE PLOTS OF THE PEONY PAVILION AND PEONY IN LOVE}

Lisa See's novel Peony in Love (2007) was inspired by The Peony Pavilion and The Three Wives' Commentary on The Peony Pavilion. The Peony Pavilion is a Chinese opera which can run for more than 22 hours and it is compared to Shakespeare's Romeo and Juliet because of the impact of the love story line, and to Goethe's The Sorrows of Young Werther, as it started the fashion for suicides among young women. In her dream, the main character Du Liniang encounters a young scholar, later in the play identified as Liu Mengmei, whom she has never met in real life. Liu's advances start off a flaming romance between the two. Du Liniang becomes preoccupied with her dream affair and her lovesickness quickly consumes her, as unable to recover from her fixation she wastes away and dies. The Three Wives' Commentary on The Peony Pavilion involves the three wives' "spiritual communication" through their follow-up commentaries on the play. They were married to the same scholar, one after another, when the previous wife died at a young age. "As soon as they were introduced to the play and to the previous wife's commentary, they were all moved by the affective power radiating from the play and by a tacit understanding that bound them together." (Chiu 1997: 10)

The protagonist of See's story, Peony, falls in love with a young stranger, and her life parallels loosely that of Liniang's. Peony is deeply moved by the text and performance of The Peony Pavilion, having extensively written about her feelings and reactions to love in her copy of the text. On the evening of the opera performance, Peony accidentally meets a handsome young man. After three nighttime meetings, Peony falls in love, but she also falls into deep despair, feeling doomed because she is trapped in an arranged marriage. Following the example of Du Liniang, she starves herself to death, only to learn right before her death that the man her father has picked for her is Wu Ren, the man she loves.

Most of the novel Peony in Love takes place after Peony's death. Because her funeral rituals are not concluded properly, she becomes a 'hungry ghost', who wanders far beyond the inner world of women. She receives the freedom she was deprived of by the customs ordering the closure which constrained her in her youth. In the process, she encounters a number of women writers who lament the difficulty of having their voices heard in a male-dominated world. From her dead grandmother she learns many painful details about her family's past, the details later amplified by Peony's mother. Peony comes to learn 
about the courage and extreme suffering of both older women and she realizes that the sternness her mother treated her with as a girl was only her attempt to protect the daughter from the evils of the outside world.

Peony shows her enduring love for Ren by exerting her influence on his second wife, although she later realizes that she may have gone too far so that she actually harmed the girl. Feeling guilty, she puts herself in self-exile, wandering around Hangzhou, until her mother convinces her to go back and compensate it to Ren and his second wife. Peony chooses a young and neglected girl to 'guide' and she slowly molds her into a lovely lady. Ren, a lonely widower, marries the girl as his third wife. Some time later, the third wife starts reading Peony's and the second wife's writings, and after adding onto them her story she convinces her husband to help her publish them. Not long after Ren realizes that Peony has never been given the appropriate funeral rites and finally completes them for her. Peony is no longer a hungry ghost, but a spirit who with great joy looks forward to meeting her husband again in the afterworld. ${ }^{1}$

\section{FUNCTIONS OF FOOD IN THE NOVEL}

Mentioned in many parts of the story, food plays different roles and functions in the life of the protagonist. The analysis aims to show the scope of the possibilities of its occurrence and to discuss the meanings embedded in the specific described culture.

\section{Food as currency}

Food is pictured as a method of payment in many situations in the novel. Particularly, women and their fates are connected with product exchange. Their value is compared with and depends on the value of food someone is going to give to have power over female lives. Peony mentions food as an element of her dowry:

My father had provided a sizable dowry for me that included fields, silk weaving enterprises, stock animals, and more than the usual amount of cash, silk, and food ${ }^{2}$, but a marriage where the wife had too much money was never happy. (See 2008 [2007]: 22)

This context shows the value of food and its role in the premarital contracts. Sometimes - as in the case of the servants and the poor - the worth of animals that may be eaten is compared to the price of human life.

"Today I go to my third owner," she said matter-of-factly. "Your father has sold me for pork and cash. It's a good deal, and he's happy." Sold for pork? I was to be married in exchange for bride-price gifts, which included 
pigs. Perhaps Willow and I were not so different after all. Neither of us had any say in our futures. (See 2008 [2007]: 70)

The strongly patriarchal society treated women as objects, whatever their status was. Their fate was similarly difficult. In the case of the poor, that simple product exchange used to reveal and expose the actual nature of the deals, whereas in the case of the rich the business transactions were hidden in the form of the highly elaborated rituals.

\section{Magical and symbolic meaning of food}

Certain meals have a special meaning, particularly during ceremonies and the rites of passage. The way and the time they are eaten or should not be eaten are strictly connected with customs and rules that should be precisely obeyed to bring luck and fertility. The same products can be used to denote different meanings, as it is in the case of pork in the following fragment.

I wouldn't be allowed to eat during the course of my wedding ceremonies, but I needed to taste a bit of the special foods my family had prepared for my wedding-day breakfast. I wasn't hungry, but I would do my best to obey, because every bite would be an omen of a long life in harmony with my husband. But no one offered me pork spareribs, which I was supposed to eat to give me the strength to have sons, while refraining from gnawing the bones to protect the vitalization of my husband's fertility.

They would want me to eat the seeds of the water lily, pumpkin, and sunflower to bring many sons. (See 2008 [2007]: 93)

The symbolic power of flesh, flowers, and vegetable seeds is worth noticing, as are also the attitudes of the patriarchal society where girls could be sold for pigs and the main reason of getting married was having sons. The future mothers should do everything possible to make their children healthy and virile, which included a special diet.

"Mistress Ze, rest, avoid gossip, and eat the proper foods. Stay away from water chestnuts, musk deer, lamb, and rabbit meat." "And make sure you wear a daylily pinned to your waist," the diviner added. "It will help relieve the pains of childbirth and ensure the birth of a healthy son." (See 2008 [2007]: 190)

Naming a fruit typical of specific geographical areas, for example taro - one of the popular edible root vegetables in large parts of Asia - enriches the descriptions with exotic tastes. Not only fruit but also other parts of plants are used for ritual purposes: 
The men left, and my aunts and cousins washed my limbs, only they forgot to add pomelo leaves to the water. [...]. Whole taro roots were placed around me as symbols of fertility. I looked like an offering to the gods. (See 2008 [2007]: 94)

The magical way of thinking about the connection between body and food depends not only on the ways people consume the produce, but also on the way their skins get into contact with it. The primary purpose and duty of a woman being fertile - is strongly underlined together with the relation between the real world and the world beyond. Female body becomes an offering to gods. The human flesh lying alongside fruit and vegetables was supposed to have a purifying and symbolic meaning.

\section{Ceremonial function}

In Chinese culture, the traditional, ceremonial meal prepared to celebrate the living and deceased ancestors is of great importance. Worshiping the ancestors was a culmination of the highest moral virtue - filial piety (Chinese: 孝, xiào).

I was not the first in my family to go to the ancestral hall this morning. We all wish for wealth, good harvests, and offspring, and already offerings of food had been made to encourage reciprocal gifts of fecundity from our ancestors. I saw whole taro roots - a symbol of fertility - and knew that my aunts and the concubines had been here to ask my ancestors to bring sons to our line. My grandfather's concubines had left little piles of fresh loquats and lychee. [...] My uncles had brought rice to ensure peace and plenty, while my father had offered a warm platter of meats to encourage more wealth and a good crop of silkworms. Chopsticks and bowls had been provided for my ancestors as well, so they might dine with elegant ease. (See 2008 [2007]: 41, 42)

Meat and alcoholic beverages played a significant role in the feeding of ancestors. These liquid refreshments were heated up over fires, so that the raising smoke, fumes, and odors accompanied by music summoned the ghosts of ancestors. "During feasts the same dishes, or whatever was left of them by the ancestors after saturating themselves with their essence until being full, were 'once again' eaten by their descendants on their behalf" (Trauffer 2009: 153). A bond between the living and the ancestors is formed by eating from the same bowl. In return, the latter bless their successors (feast attendees or a representative of the ancestors acknowledges receiving the sacrifice and wishes the host all the best from the ancestor). Hence, communication is bidirectional - between the living and the dead. 
If the deceased did not have any offspring to feed them, they became 'hungry souls' - they wandered around with the living and did them harm. To stay safe, hungry souls were also fed - in case they wondered the streets, tables with offerings were left outside houses on set dates (Trauffer 2009: 157). The fate of being the hungry ghost was known to Peony:

I was reduced to an open mouth and an empty stomach. Gods and ancestors are worshipped and cared for as social superiors. They give protection and grant wishes; the celestial aspect of their souls is associated with growth, procreation, and life. Their offerings are carefully cooked and presented on beautiful platters with plenty of serving and eating implements. But ghosts are despised. [...] Instead of trays of ripe peaches, fragrant steamed rice, and whole soy-sauce chickens, we receive uncooked rice, vegetables that should have been fed to the pigs, chunks of turned meat with hair still on it, and no bowls or chopsticks. We're expected to shove our faces into this food like dogs, rip it apart with our teeth, and carry it away to dark nether corners.

[...] I fought off others more timid than myself for the peel of a mildewed orange or a piece of bone that hadn't already been sucked of its marrow. (See 2008 [2007]: 162-164)

The food Peony was fighting for as a ghost is contrasted with the quality meals prepared by her family to be offered to the ancestors. Not only did the deceased benefit from the offerings, but also the poor were fed on such holidays.

I remembered how the servants had worked for days, chattering among themselves about the wealth of food that they'd placed, tied, or strapped to the altar before our gate: chickens and ducks, dead and alive; slices of pork and pigs' heads; fish, rice cakes, and whole ripe pineapples, melons, and bananas. When the festival was over and the ghosts had eaten their share of the spiritual meal, beggars and the destitute would come to partake of the carnal leavings in the form of an ample banquet courtesy of the Chen family. (See 2008 [2007]: 162-164)

Apart from life, health and illness, also the rituals concerning death are strongly related to different usages of particular nutritious products. Their real power is bound with the symbolic one ascribed to certain edible items, which is described in the passage below.

On the third day after my death, my body was placed in my coffin, along with ashes, copper coins, and lime. [...] My aunts put cakes in my hands, and my uncles laid sticks on either side of my body. They gathered together clothes, binding cloth for my feet, money, and food-all made from paper- 
and burned them so they would accompany me to the afterworld. (See 2008 [2007]: 101)

The custom of feeding the dead was present in the Slavic pagan tradition too, when real food was brought to the graveyards to be shared with the deceased, and the belief that in the afterworld people would need basic things they used in their lives on Earth was also common. The rituals relating to the forefathers the Dziady - took place in accordance with the principal that spirits may do favors for the living and the living can do favors for the dead. In some regions of Poland, the custom of feeding ancestral souls by offering food and drinks was practiced until the early twentieth century (Warnke 2015).

\section{Social functions}

Festivals and birthdays were good occasions to prepare special meals. Different emotions, both good and bad, can influence appetite, which is presented in the following excerpt:

I couldn't eat, however, not even the special dumplings that Mama had Cook prepare for my birthday. How could I put food in my mouth and swallow it when my stomach was still so unsettled - from the binding, from my secret happiness, and from my worries about being caught tonight? (See 2008 [2007]: 47)

The cultural role of food may also be seen in various combinations of dishes even if it is described in a very general way, for example, one can expect tea and biscuits or coffee and cake in one region and dumplings in another geographical area:

When my aunts or cousins came to invite me to take a walk in the garden or join them for tea and dumplings in the Spring Pavilion, I graciously thanked them but said no. (See 2008 [2007]: 79)

The meals eaten with family members had educative, social, and intellectual functions, which is reflected in the brief passage from the analyzed novel:

Come to the Spring Pavilion. Have breakfast and listen to your aunts. Come for lunch and learn how to treat your husband's concubines. Join us at dinner and perfect your conversation. (See 2008 [2007]: 79)

The quality of food and the ritual way it was served were connected with showing love and respect. It was also a good way of building relationships and maintaining proper social positions: 
I insisted Ze follow these rituals to appease her husband's anxiety and earn her mother-in-law's respect. When Ze cooked, she made sure that all the flavors were compatible and that the food was fragrant. She brought to the dinner table fish from West Lake and watched quietly to make sure the others enjoyed the taste. She poured tea when her mother-in-law's or husband's cup was low. (See 2008 [2007]: 174)

It is not enough to cook only a meal to build a social relation based on food. The meal needs to have certain qualities to taste, smell, and look appropriate to match the expectations of the ones it is prepared for. Being very empathic, observant, and sensitive to the signs shown by the others is a good description of the high-context culture relationships.

\section{Food as a medicine}

Being a remedy for body and soul diseases is another function of food. In holistic medicine, what a person eats is believed to be strictly connected with who he or she is, because while eating bits of the world, one reconstructs it in oneself (Beinfield \& Korngold 1997 [1995]: 273). The substances produced in modern pharmacy have their roots in herbal knowledge: originally, aspirin was produced from willow bark, morphine - from poppy seeds, and penicillin - from fungi (ibid.: 231). The tradition of using food as medicine is especially strong in the Chinese culture. Different stages of life, connected with a particular role or situation, are related to the specific type of food that should be eaten to keep body and soul healthy. The female cycle was strongly influenced by that procedure, as women were supposed to be beautiful and breed children, so the special meals and herbs were used on many occasions to make their chances to fulfil that duty better. That was also true when people wanted to correct the nature and change their appearance. One of the intrusive methods to 'improve' the natural look was crushing foot bones to make feet as small as possible. The practice was accompanied by carefully prepared dishes, described in the novel. We can learn what was served before and after foot-binding to make the bones break and heal better, for example:

I'll send congee for the child. Make sure she eats it, and then give her some herbs to ease the pain. (See 2008 [2007]: 47)

Certain products were also carefully chosen for fertility reasons and as means of healing the weak body and soul:

He brought her little gifts. He asked the servants to prepare special foods that would entice and stimulate her. (See 2008 [2007]: 159) 
When Ren assured the doctor this wasn't possible, he prescribed a diet of pig's trotters to help restore Ze's qi. She was not about to eat something so lowly. Next the doctor ordered the cook to make a soup of pig's liver to help strengthen Ze's corresponding organ. Soon he was trying every organ of the pig to fortify his patient. None of them worked. "You were supposed to marry someone else," the doctor said diffidently to Ren. "Perhaps she's come back to claim her rightful place." Ren dismissed the idea. "I don't believe in ghosts.” (See 2008 [2007]: 188)

The observations to diagnose the relations between the type of nutrition used and the specific malfunctioning behavior is typical of Chinese medicine responsible not only for the welfare of the body, but also for the influence of the sick person on the environment. The harmony with nature and with others is the main purpose of seeking balance in the diet. ${ }^{3}$ There are some cases described in the novel, where feelings and moods are treated with food and where the state of mind is strongly connected with an appetite or lack thereof.

"Your wife has a different kind of lovesickness from what I originally thought. She has a bad case of that most common of all feminine disorders: too much vinegar." This word sounded exactly the same as jealousy in our dialect [...] Many wives go on hunger strikes because they're jealous and ill-tempered," the doctor suggested, trying a different approach. "They try to push their anger onto others by making them suffer with guilt and remorse."

The doctor prescribed a bowl of jealousy-curing soup made from oriole broth. (See 2008 [2007]: 188)

In fact, in Mandarin Chinese 醋 - cù means 'vinegar' and 'feeling of jealousy', 醋意 - cù yì includes the character of 'vinegar' and 意 - yì ‘idea, meaning, wish, desire', so the concepts are linguistically related. Sometimes the food used as medicine had its negative effect, which was to be calculated into the curing process:

This remedy had been used on the jealous wife. It had reduced the wife's emotional disease by half but left her pockmarked. "You would ruin me?" Ze pushed away the soup. "What about my skin?” (See 2008 [2007]: 188)

Not always, the therapy was fully successful - sometimes it had side effects, when cleaning the soul made the body ugly. Then the value system of the treated was crucial in making a decision about priorities in healing. 


\section{Deprivation of food: Self-control}

The anorectic behavior and its consequences are described in a detailed way: the body changes and so does the attitude towards it, as presented in the following passages:

For the next seven weeks, Shao brought my meals, but my stomach had become an abyss of anguish and I ignored the food or stubbornly pushed it away. As time passed, my body changed. My skirts started to hang on my hips instead of my waist, and my tunics swung loose and free. (See 2008 [2007]: 70)

She refused to light the lamps. She didn't speak. She turned down food even when it was brought to her. She stopped dressing and pinning her hair. (See 2008 [2007]: 187)

The reasons for gaining power over the body by starving it are also clearly highlighted:

"You didn't crush me. You didn't steal my breath. I stopped eating, and for once I had total control over my destiny. I wanted to starve that thing you put in my belly." (See 2008 [2007]: 267)

This case was complicated as the mother-to-be did not want to be pregnant, because she felt the baby was forced into her. Therefore, she was not willing to make it grow and by controlling her life she also took the decision about the future of her child.

The influence of the reality on The Peony Pavilion is also worth mentioning. The suicide rate of women was very high at the time of Tang Xianzu because of the external conflict between the parents' practical considerations and the couple's affective passion. It is said that in the author's home town of Lin-Chuan, one out of every eight women was a "virtuous widow" or "martyr virgin" (Chiu 1997: 13). The popularity of the opera encouraged the followers of Liniang to die of starvation.

In China, young educated women from wealthy families - typically between the ages of thirteen and sixteen and with their marriages already arranged were particularly susceptible to the story. Believing that life imitates art, they copied Liniang: They gave up food, wasted away, and died, all in hopes that somehow in death they might be able to choose their destinies, just as the ghost of Liniang had. (Author's note; See 2008 [2007]: 277)

These acts of copycat suicides were repeated in history. In Europe, they are connected with the Werther effect, i.e., the suicides inspired in the eighteenth 
century by Die Leiden des jungen Werthers (The Sorrows of Young Werther) by Johann Wolfgang von Goethe. Young men mimic the main character by dressing like him in yellow pants and blue jackets and some of them, especially those who were rejected by women they loved, like their hero, used to shoot themselves with a pistol in an act of hopelessness. This resulted in the book being banned in several places. To this day, the book belongs to the canon of literature.

The copycat suicides still happen nowadays, but they follow the examples of the ones presented in mass media. The kind of quick and violent death chosen by men is significantly different from the female self-starvation. This type of death chosen by women may be strictly connected with the assumption that while in almost every culture there is a profound linkage, or sacred balance, between the two primal activities, eating and reproduction, it is a woman who "contains and, to some degree, assimilates the mate that enters her body, just as she does the food she eats" (Allen 2000: 30). When the possibility of consuming the feelings is not there, the appetite for life also disappears.

While anorexia became more commonly diagnosed during the twentieth century, and the term anorexia nervosa was first used by William Gull in 1873 to describe this condition, it is still unclear if that late appearance was due to an increase in its frequency or simply in consequence of its better diagnosing. ${ }^{4}$ It is observed to occur mostly among women and is up to ten times less ( 5 to 10 percent of the cases) likely among men (Niewiadomska \& Kulik \& Hajduk 2005: 224). ${ }^{5}$ Often it begins during the teen years or young adulthood. Lisa See writes about the contemporary problem of anorexia, but claims that it has also been present in different times and cultures:

No one knows for sure what killed the lovesick maidens, but it may have been self-starvation. We tend to think of anorexia as a modern problem, but it isn't. Whether it was female saints in the Middle Ages, lovesick maidens in seventeenth-century China, or adolescent girls today, women have had a need for some small measure of autonomy. (Author's note; See 2008 [2007]: 277)

\section{FOOD-RELATED WORDS}

There are multiple instances of using food-related terms in the book. They occur in various forms and on different levels - from the very general to the more specific ones - including hyperonyms, hyponyms, and co-hyponyms. The following groups can be distinguished: keywords describing food as such - food, meal, dish; those naming more specific kinds of it - meat, fruit, vegetable, seeds; 
the detailed ones such as melon, pork. More vocabulary related to food comprises verbs - eat, cook, prepare, taste, serve, gnaw; nouns - flavors, taste, smell, fragrance, aroma; and adjectives - fragrant, stinky, sweet, sour, salty, bitter. Meals are associated with the time of the day when they are served - breakfast, lunch, dinner; special occasions - parties, banquets, weddings; and utensils used during the meals - bowls, spoons, plates, chopsticks, trays, cups. Sometimes the symbolic name, the whole recipe and the explanation of the expected results are given, making the description very informative and highly culture-bound, for example, "dragon hoof send child" - "pig leg with ten kinds of patrimonial seasonings braised over a slow fire - which was reputed to bring sons'.

Among the vocabulary mentioned in the novel, there are names of various kinds of food: fruit (pineapples, melons, bananas, peaches, cherries, oranges, lychees, pomelos, water chestnuts, taro roots), vegetables (red beans, mushrooms), rice (steamed rice, sticky, uncooked rice), seeds (of the water lily, pumpkin, sunflower). Meat plays a special role in the described cuisine, especially pork (pig's trotters, liver, slices of pork and pigs' heads, pork spareribs). Other meat names comprise the following terms: hen, chicken (soy-sauce chickens), duck, a warm platter of meats, sweetmeats, musk deer, lamb, rabbit meat. Some other alimentary products include such lexical items as the bones, fresh loquats, scallions, salted fish, eggs, dessert, (rice, malt) cake, soup, herbs, tea, riverbank grass, spices, vinegar, walnuts.

The xenisms naming the meals or products used to prepare them in the original language forms have strong foreignizing effects, which is exploited in many literary works. In this particular novel, the food vocabulary typical of the described culture is rather general and given without the Chinese original names. Some specific and popular types of food include sweet-bean paste dumplings, cock's blood, taro roots, ginger, rice wine, carambolas, rice cakes, riverbank grass, pomelo, water chestnuts, lychees, dragon eyes (longan fruit traditional Chinese: 龍眼, pinyin: lóngyăn - it resembles an eyeball when its fruit is shelled).

The author uses developed descriptions in quotes ("dragon hoof send child") or italicization (e.g. congee) to mark the foreign character of a given element. Nevertheless, it plays the role of an ornamentalized display of the insider's knowledge, "linguistic exhibitionism at its finest" (Pandey 2016: 98). The culture-specific character of the described cuisine manifests itself not only in the presence of product names, but also in the absence of the others. China is associated with tea - there are as many as 54 instances of it being mentioned in the novel (e.g. jasmine, green tea), but the term coffee does not appear in the analyzed text. Rice is mentioned frequently (20 times), but potatoes or pasta ${ }^{6}$ are not referred to at all. The word wine occurs 27 times, but there is no mention of vodka or beer; similarly, the lexical item chopsticks is used (5 occurrences), but not forks. 
This type of presenting the cultural background reinforces the stereotypical views on the Chinese cuisine, which is believed to consist of carefully prepared portions of steamed vegetables, small bites of meat, and bowls of noodles or rice eaten with chopsticks. Such meals are accompanied by green or jasmine tea (cf. Zhu 2010). This view is a simplification as diverse regions of China are famous for their various types of meals and preferences for different tastes, spices, and ingredients rarely used in the Western world or entirely unknown to it.

\section{CONCLUSIONS}

The nourishment-related scenes described in the novel Peony in Love show many possibilities and functions of food and the meanings that could be attached to it in symbolic, culture-specific, and universal ways. We can find a very broad spectrum of examples and ways in which food is used in the novel. Food plays the role of a currency, has magic powers, and is used in ceremonies connected with the whole ritual year. It is treated as a medicine and it has very distinctive social purposes. It is vital for people who are alive; its lack makes people die, but they still need it in their afterlives. The descendants of the deceased should realize the importance of food and provide it to their living and dead relatives regularly in the highest possible quality. Finally, food is a means of control - both enforced by the society and more individual one - giving the feeling of power over one's own body and the ability to decide if one wants to feed it or rather make it disappear.

The idea of ruling over one's body by means of food shows once again how strictly body and soul, physical and psychical sides are related. Not only do the circumstances, rituals, availability of products, customs, and hunger determine the choices of what, when, and with whom one eats, but also the quantity and quality of meals conditioned by one's welfare and staying alive. Culture influences to a high degree not only the culinary habits, but also beliefs and feelings crucial in making the decision about what one wants to do with one's body and whether one wants to eat at all.

Chinese food is not unique in its cultural weight. However, unlike in most Western cultures, the various cuisines of China have retained a strong emphasis on the non-material meanings of food as explicit, widely acknowledged and discussed. Food preparation and ingestion are central to most social, religious and medicinal activities. Chinese people do not eat simply for nourishment of the body or for enjoyment. They have an intricate network of meanings, prescriptions and proscriptions which are explicitly wielded in the daily construction of foodways. (Davis 2002: 77) 
This abundance of meanings is present in the described novel on different levels - showing the importance of food for human life and death alike, and proving the view on food itself stated by the food studies icons, who claim that food is "a system of communication, a body of images, a protocol of usages, situations, and behaviour" (Barthes 2013: 24). "Food touches everything and is the foundation of every economy, marking social differences, boundaries, bonds, and contradictions - an endlessly evolving enactment of gender, family, and community relationships" (Counihan \& Van Esterik 2013: 3).

\section{NOTES}

1 For the details of the plot and contemporary performances, see, e.g., Lunden 2012, Lam 2006, Zemke 2011, https://en.wikipedia.org/wiki/The_Peony_Pavilion; https:// en.wikipedia.org/wiki/Peony_in_Love, both last accessed on 6 February 2018.

${ }^{2}$ Hereinafter emphases added.

3 "Chinese food is divided into two things; it's cold or hot. The varied religious traditions of China can illuminate the Chinese extra-material investment in food. Whether Taoist, Buddhist or Confucianist, the human body is seen as a microcosm of the universe. ... Balancing concepts of yin and yang are reflected in the compositions of most dishes and menus." (Davis 2002: 77)

4 Categorizing anorexia as an eating disorder is problematic: many cases might more readily be called exercise disorders, and every case is an ascetic disorder (O'Connor \& Van Esterik 2008: 6).

5 Others claim that while most sociocultural explanations treat anorexia as a women's disease, men make up from one-fifth (full syndrome) to one-third (full or partial syndrome) of sufferers (O’Connor \& Van Esterik 2008: 6).

6 About Chinese noodles and viticulture cf. Höllmann 2013: 150.

\section{REFERENCES}

Allen, Gary 2000. Desire on the Menu. Journal for the Study of Food and Society, Vol. 4, No. 2, pp. 29-38. http://dx.doi.org/10.2752/152897900786732808.

Barthes, Roland 2013. Toward a Psychosociology of Contemporary Food Consumption. In: Carole Counihan \& Penny van Esterik (eds.) Food and Culture: A Reader. Third edition. New York \& London: Routledge, pp. 23-30.

Beinfield, Harriet \& Korngold, Efrem 1997 [1995]. Medycyna chińska. [Chinese Medicine.] Warszawa: W.A.B.

Chiu, Tzu-shiu 1997. A Dream or a Nightmare? A Semiotic Feminist Reading of Mu-dan Ting (The Peony Pavilion). Tamkang Review, Vol. 27, No. 3, pp. 293-310. 
Counihan, Carole \& Van Esterik, Penny 2013. Why Food? Why Culture? Why Now? Introduction to the Third Edition. In: Carole Counihan \& Penny Van Esterik (eds.) Food and Culture: A Reader. Third edition. New York \& London: Routledge, pp. 1-18.

Counihan, Carole \& Van Esterik, Penny (eds.) 2013. Food and Culture: A Reader. Third edition. New York \& London: Routledge.

Davis, Netta 2002. To Serve the "Other": Chinese-American Immigrants in the Restaurant Business. Journal for the Study of Food and Society, Vol. 6, No. 1, pp. 70-81. http://dx.doi.org/10.2752/152897902786732707.

Höllmann, Thomas O. 2013. The Land of the Five Flavors: A Cultural History of Chinese Cuisine. Series: Arts and Traditions of the Table: Perspectives on Culinary History. Transl. by Karen Margolis. New York: Columbia University Press. DOI: 10.7312/ holl16186.

Lam, Andrew 2006. The Deaths and Lives of The Peony Pavilion. California Magazine, July/August. Available at http://alumni.berkeley.edu/california-magazine/ july-august-2006-indo-chic/deaths-and-lives-peony-pavilion, last accessed on 28 February 2018.

Lunden, Jeff 2012. ThePeony Pavilion: A Vivid Dream in a Garden.NRP music, November 30. Available at http://www.npr.org/sections/deceptivecadence/2012/11/30/166153763/ the-peony-pavilion-a-vivid-dream-in-a-garden, last accessed on 28 February 2018.

Maslow, Abraham H. 1954. Motivation and Personality. New York: Harper \& Brothers. Available at http://s-f-walker.org.uk/pubsebooks/pdfs/Motivation_and_PersonalityMaslow.pdf, last accessed on 7 February 2018.

Niewiadomska, Iwona \& Kulik, Agnieszka \& Hajduk, Agnieszka 2005. Jedzenie. [Food.] Lublin: KUL.

O’Connor, Richard A. \& Van Esterik, Penny 2008. De-Medicalizing Anorexia: A New Cultural Brokering. Anthropology Today, Vol. 24, No. 5, pp. 6-9. http://dx.doi. org/10.1111/j.1467-8322.2008.00611.x.

Pandey, Anjali 2016. Monolingualism and Linguistic Exhibitionism in Fiction. London: Palgrave Macmillan.

See, Lisa 2008 [2007]. Peony in Love. New York: Random House Trade.

Trauffer, Regula 2009. Chiny: uroczysty posiłek ku czci żywych i przodków. [China: Festive Meal to Commemorate the Living and the Ancestors.] In: Franz-Theo Gottwald \& Lothar Kolmer (eds.) Jedzenie: Rytuaty $i$ magia. [Food: Rituals and Magic.] Transl. by Elżbieta Ptaszyńska-Sadowska. Warszawa: Muza SA, pp. 153-160.

Warnke, Agnieszka 2015. 9 Slavic Rituals \& Customs of Ye Olden Days. Culture.pl, 9 November. Available at http://culture.pl/en/article/9-slavic-rituals-customs-ofye-olden-days, last accessed on 7 February 2018.

Zemke, Marika 2011. Q\&A: Lisa See. Library Journal: Library News, Reviews and Views, 15 May.

Zhu, Song 2010. Xenophobe's Guide to the Chinese. London: Oval Books.

Zwoliński, Andrzej 2006. Jedzenie w relacjach społecznych. [Food in Social Relations.] Kraków: WNPAT.

\section{INTERNET SOURCES}

Chinese English Dictionary. Available at http://www.chinese-tools.com/tools/dictionary. html, last accessed on 6 February 2018. 